\title{
Synthesis and characterization of naphthalene diimide polymers based on donor-acceptor system for polymer solar cells
}

\author{
Q. Xu ${ }^{1}, J$. Wang $^{2}$, S. Chen ${ }^{1}$, W. $L i^{2}, H$. Wang $^{1}$
}

${ }^{1}$ State Key Laboratory for Modification of Chemical Fibers and Polymer Materials, The Key Laboratory of High-Performance Fiber and Product, Ministry of Education, College of Materials Science and Engineering, Donghua University, 201620 Shanghai, P R China

${ }^{2}$ Laboratory of Materials Science, Shanghai Institute of Organic Chemistry, Chinese Academy of Sciences (CAS), 345 Lingling Road, 200032 Shanghai, China

\begin{abstract}
Three donor-acceptor (D-A) naphthalene diimide copolymers, poly \{thieno[3,2-b]thiophene-diyl-alt-N,N'-bis(2octyldodecyl)-naphthalene-1,4,5,8-bis(dicarboximide) $\}$ (P1), poly \{4,8-dioctyloxybenzo[1,2-b;3,4-b']dithiophene-diyl-altN,N'-bis(2-octyldodecyl)-naphthalene-1,4,5,8-bis(dicarboximide) $\}$ (P2), and poly $\{4,8$-bis(2-ethylhexyloxy)benzo[1,2b:4,5-b']dithiophene-diyl-alt-N,N'-bis(2-octyldodecyl) -naphthalene-1,4,5,8-bis(dicarboximide) $\}$ (P3), were synthesized by Stille coupling reaction. All copolymers showed good solubility in common organic solvents with broad absorption region and narrow optical band gap. The electrochemical properties of the polymers can be adjusted by changing the donor segment. P1 showed n-type characteristic while $\mathbf{P} 2$ and $\mathbf{P} 3$ showed p-type characteristic. All-polymer solar cells using P3HT as the donor and $\mathbf{P 1}$ as the acceptor were fabricated and the highest power conversion efficiencies (PCEs) of $0.068 \%$ were obtained under the preliminary condition. Moreover, p-type naphthalene diimide copolymers (P2 and P3) based on D-A system were used as donors to fabricate bulk heterojunction polymer solar cells (BHJ, PSCs) for the first time, and the maximum power conversion efficiencies PCEs were about 0.021 and $0.017 \%$, respectively.
\end{abstract}

Keywords: Tailor-made polymers, polymer solar cells (PSCs), naphthalene diimide, donor-acceptor

\section{Introduction}

The continually growing demand for energy throughout the world has attracted great attention on the exploration of new energy types. The utilization of the photovoltaic effect to generate electricity from solar energy, which is known as a clean and renewable energy source, represents an effective way to solve the energy shortage [1]. Polymer solar cells have drawn considerable attention because of their low-cost, light weight, flexibility, inkjet printing process and large-area fabrication [2-4]. Over the last decade, the performance of polymer solar cells
(PSCs) has been significantly improved owing to the synthesis of novel photovoltaic materials, as well as device optimization. Nevertheless, there are still several issues regarding to PSCs such as solution processing, low power conversion efficiencies and stability compared with silicon solar cells [5]. So far, bulk heterojunction solar cells, which are composed of an interpenetrating network of donors and acceptors, have played a leading role in fabricating PSCs due to better performance at carrier transmission [6]. The most typical bulk heterojunction (BHJ) solar cells are using poly(3-hexylthio-

\footnotetext{
${ }^{*}$ Corresponding author, e-mail: chensy@dhu.edu.cn

(C) BME-PT
} 
phene) (P3HT) as donor and [6,6]-phenyl-C61butyric acid methyl ester $\left(\mathrm{PC}_{61} \mathrm{BM}\right)$ as acceptor, however, it's challenging to improve the power conversion efficiencies (PCEs) over 5\% due to the intrinsic absorption limit of $\mathrm{P} 3 \mathrm{HT}$ and the weak absorption in the visible region of $\mathrm{PC}_{61} \mathrm{BM}$ [7].

Therefore, it is necessary to design and synthesize conjugated polymers with expected properties, such as low band gap, broad absorption range, high mobility, appropriate molecular energy levels and easy processing. Recently, some excellent works with the PCEs over 7\% have been extensively reported, such as Yu et al. reported a PCE of 7.4\% [8]. In order to improve the absorption property, introducing the D-A system to the polymers has been proved to be an efficient approach, in which conjugated electronrich (donor) and electron-deficient (acceptor) units are alternatively copolymerized to manipulate optical band gap and optimize the HOMO and LUMO energy levels via intramolecular charge transfer (ICT) [9]. Semiconducting materials with strong electron-withdrawing groups comprising the structure of naphthalene diimide (NDI) and perylene diimide (PDI) have been used as acceptor units in the conjugated polymers [10]. In particular, NDI based polymers attract a great deal of attention recently due to the reports on the merit of their facile soluble processing for organic field effect tranistors (OFETs) and PSCs device [11, 12]. As an acceptor unit, NDI can be copolymerized easily with a wide variety of donor units to adjust the optoelectronic properties of the resulting polymers $[13,14]$. This NDI unit has a large planar structure which is favorable for the electron delocalization along the polymeric backbone [15].

In this study, we synthesized three NDI-based polymers by combination of NDIs with different donor segments, including thienothiophene and dibenzothiophene derivatives. We obtained P1 as n-type polymer, $\mathbf{P} \mathbf{2}$ and $\mathbf{P 3}$ as p-type polymers. $\mathbf{P 1}$ with a rigid structure has a better absorption in the visible region than $\mathrm{PC}_{61} \mathrm{BM}$. In addition, it shows good solubility in common organic solvents comparing with $\mathrm{PC}_{61} \mathrm{BM}$, so it was used as acceptor unit and P3HT as donor unit to fabricate all-polymer blends PSCs. For different alkoxy side chain, P2 and P3 show excellent solubility and they have closed energy level with a lower band gap than P3HT, so they were used as donor unit and $\mathrm{PC}_{61} \mathrm{BM}$ as acceptor unit to fabricate PSCs. The PCEs of the PSCs based on P1,
P2 and P3, under standard global AM 1.5 solar conditions, were $0.068,0.021$ and $0.017 \%$, respectively. As all of the devices have very low short-circuit density, and the performance of the devices has big improvement possibility. We consider that the reason could be the difficulty in forming the interpenetrating networks which are necessary for efficient transport of both electrons and holes to the electrodes.

\section{Experimental}

\subsection{Measurements and characterization}

${ }^{1} \mathrm{H}$ NMR (300 or $400 \mathrm{MHz}$ ) spectra were measured in $\mathrm{CDCl}_{3}$ on Varian Mercury (300 or $400 \mathrm{MHz}$ ) instruments, using tetramethylsilane as an internal standard. Elemental analyses were performed on an Elementar Vario EL III elemental analyzer. Electronic absorption spectra were measured on a U3900 UV-vis spectrophotometer. TGA measurements were carried out on a TA Q500 instruments under a dry nitrogen flow at a heating rate of $10^{\circ} \mathrm{C} / \mathrm{min}$, from room temperature to $500^{\circ} \mathrm{C}$. DSC analyses were performed on a TA Q20 instrument under nitrogen atmosphere at a heating (cooling) scan rate of $10^{\circ} \mathrm{C} / \mathrm{min}\left(0-280^{\circ} \mathrm{C}\right)$. Cyclic voltammetric measurements were carried out in a conventional threeelectrode cell using a platinum button working electrode of $2 \mathrm{~mm}$ diameter, a platinum wire counter electrode, and a silver-silver chloride reference electrode on a computer-controlled CHI610D instruments. AFM was recorded on a Nanoscope IIIa atomic force microscopy (AFM) in tapping mode.

\subsection{Materials}

1,4,5,8-Naphthalenetetracarboxylic dianhydride (NTCDA, 95\%) was purchased from Aladdin (China). 3-Bromothiophene (97\%) was purchased from Alfa Aesar. Benzo[1,2-b:4,5-b']dithiophene4,8-dione (97\%) and trimethyltin chloride (1.0 $\mathrm{M}$ in hexanes) were purchased from Aldrich. All the chemicals not mentioned before were purchased from Sinopharm Chemical Reagent Co. (China) and used as received. Tetrahydrofuran (THF), diethyl ether and toluene were dried by distillation from sodium/benzophenone under nitrogen. Similarly, N, N-dimethyl formamide (DMF) was distilled from $\mathrm{CaH}_{2}$ under nitrogen. The following compounds were synthesized according to the procedures in the literatures: 2,6-dibromonaphthalene-1,4,5,8-tetracarboxydianhydride, 2-octyldodecylamine, 2,5-dibromothieno 
[3,2-b]thiophene, 4,8-dioctyloxybenzo[1,2-b;3,4-b'] dithiophene [16-21].

\subsection{Photovoltaic devices fabrication and characterization}

The solar cells were fabricated with a device structure ITO/poly(3,4-ethylenedioxythiophene):poly (styrenesulfonate)(PEDOT:PSS)/Polymer:PC ${ }_{61} \mathrm{BM}$ $\mathrm{Blend} / \mathrm{Ca} / \mathrm{Al}$. The ITO glass substrates were precleaned by detergent, acetone and boiling in $\mathrm{H}_{2} \mathrm{O}_{2}$. PEDOT:PSS as a hole-conducting layer was spincasted $(4000 \mathrm{rpm})$ at a thickness of about $30 \mathrm{~nm}$ from aqueous solution. The substrate was annealed at $150^{\circ} \mathrm{C}$ for $20 \mathrm{~min}$ on a hot plate. The active layer contained a blend of copolymers as electron donor or electron acceptor, which was prepared with different weight ratios of the compolymers $(1: 1,1: 2$, $1: 3, \mathrm{w} / \mathrm{w})$ in chlorobenzene $(8 \mathrm{mg} / \mathrm{mL})$. The active layers were obtained by spin coating of the blend solutions at $4000 \mathrm{rpm}$ for $30 \mathrm{~s}$ and the thickness of films were $80 \mathrm{~nm}$, as measured with the Veeco Dectak 150 profilometer IV. Subsequently, Ca $(10 \mathrm{~nm})$ and $\mathrm{Al}(100 \mathrm{~nm})$ electrodes were deposited via thermal evaporation in vacuum $\left(5 \cdot 10^{-4} \mathrm{~Pa}\right)$. The active area was about $7 \mathrm{~mm}^{2}$. Current-voltage $(J-V)$ characteristics were recorded using Oriel So13A solar simulator in dark and under $100 \mathrm{Mw} / \mathrm{cm}^{2}$ simulated AM 1.5G irradiation. All the measurements were performed under nitrogen atmosphere at room temperature.

\subsection{Synthesis}

$N, N^{\prime}$-bis(2-octyldodecyl)-2,6-dibromonaphthalene1,4,5,8-bis(dicarboximide)(1)

A mixture of 2,6-dibromonaphthalene-1,4,5,8-tetracarboxydianhydride (1.28 g, $3 \mathrm{mmol}), 2$-octyldodecylamine $(2.68 \mathrm{~g}, 9 \mathrm{mmol})$, o-xylene $(30 \mathrm{~mL})$, and propionic acid $(10 \mathrm{~mL})$ was stirred at $140^{\circ} \mathrm{C}$ for $2 \mathrm{~h}$. Upon cooling to ambient temperature, most of solvents were removed in vacuum, and the residue was purified by column chromatography on silica gel using a mixture of dichloromethane: hexane (1:3, $\mathrm{v} / \mathrm{v}$ ) as eluent. Compound $\mathbf{1}$ was obtained as a slightly yellow solid (544.4 mg, 18.3\%). ${ }^{1} \mathrm{H}$ NMR $\left(300 \mathrm{MHz}, \mathrm{CDCl}_{3}\right) \delta 0.86-0.87(\mathrm{~m}, 6 \mathrm{H}), 1.23-1.29$ (br, 32H), $1.98(\mathrm{~m}, 1 \mathrm{H}), 4.13-4.16(\mathrm{~d}, 2 \mathrm{H}), 9.00$ (s, $2 \mathrm{H})$.
2,5-Bis(trimethylstannyl)thieno[3,2-b]thiophene(2) n-Butyllithium ( $1.6 \mathrm{~mL}, 2.5 \mathrm{~mol} / \mathrm{L}, 4 \mathrm{mmol})$ was added dropwise to a mixture of 2,5-dibromothieno[3,2-b]thiophene $(596 \mathrm{mg}, 2 \mathrm{mmol})$ and THF $(20 \mathrm{~mL})$ at $-78^{\circ} \mathrm{C}$ and the resulting mixture was stirred for a further $1.5 \mathrm{~h}$ at this temperature. Then trimethyltinchloride $(4 \mathrm{ml}, 1 \mathrm{~mol} / \mathrm{L}, 4 \mathrm{mmol})$ was added and stirred for about $6 \mathrm{~h}$ at ambient temperature. Then $\mathrm{H}_{2} \mathrm{O}(20 \mathrm{~mL})$ was added to the mixture, extracted with diethyl ether, dried $\left(\mathrm{MgSO}_{4}\right)$, filtered and concentrated in vacuum. The residue was purified by column chromatography on neutral aluminium oxide using a mixture of triethylamine: hexane $(1: 20, v / v)$ as eluent, then the obtained product 2 was recrystallized in ethanol to from a white crystal (0.31 g, 33.3\%). ${ }^{1} \mathrm{H}$ NMR $(300 \mathrm{MHz}$, $\left.\mathrm{CD}_{3} \mathrm{COCD}_{3}\right) \delta 0.39(\mathrm{~s}, 18 \mathrm{H}), 7.37(\mathrm{~s}, 2 \mathrm{H})$.

\section{2,6-Bis(trimethyltin)-4,8-dioctyloxybenzo[1,2-b;3,4- $b^{\prime}$ ]dithiophene (3a)}

n-Butyllithium ( $4.4 \mathrm{~mL}, 2.4 \mathrm{~mol} / \mathrm{L}, 10.5 \mathrm{mmol})$ was added dropwise to a stirred solution of 4,8-dioctyloxybenzo [1,2-b;3,4-b'] dithiophene (2.23 g, $5 \mathrm{mmol})$ in THF $(50 \mathrm{~mL})$ at $-78^{\circ} \mathrm{C}$ and the resulting mixture was stirred for another hour at this temperature. Trimethyltinchloride $(10.5 \mathrm{~mL}, 1 \mathrm{~mol} / \mathrm{L}$, $10.5 \mathrm{mmol}$ ) was added and stirred for about $12 \mathrm{~h}$ at ambient temperature. At last $\mathrm{H}_{2} \mathrm{O}(30 \mathrm{~mL})$ was added to the mixture, then extracted with $\mathrm{CH}_{2} \mathrm{Cl}_{2}$, dried $\left(\mathrm{MgSO}_{4}\right)$, filtered and concentrated in vacuum. The residue was purified by column chromatography on neutral aluminium oxide using a mixture of triethylamine : hexane $(1: 20, \mathrm{v} / \mathrm{v})$ as eluent, then the obtained product $\mathbf{3 a}$ was recrystallized in isopropyl alcohol to from a white crystal $(3.2 \mathrm{~g}$, $82.8 \%) .{ }^{1} \mathrm{H}$ NMR $\left(300 \mathrm{MHz}, \mathrm{CDCl}_{3}\right): \delta 0.44(\mathrm{~s}$, $18 \mathrm{H}), 0.86-0.92$ (t, 6H), 1.31-1.42 (br, 20H), 1.57$1.60(\mathrm{~m}, 4 \mathrm{H}), 4.27-4.30(\mathrm{~d}, 4 \mathrm{H}), 7.51(\mathrm{~s}, 2 \mathrm{H})$.

\section{2,6-Bis(trimethyltin)-4,8-bis(2-ethylhexyloxy)benzo} [1,2-b:4,5-b']dithiophene(3b)

Compound $\mathbf{3 b}$ was synthesized according to the similar procedure as described for compound $\mathbf{3 a}$ as a white crystal $(1.67 \mathrm{~g}, 86 \%) .{ }^{1} \mathrm{H}$ NMR $(300 \mathrm{MHz}$, $\left.\mathrm{CDCl}_{3}\right): \delta 0.44(\mathrm{~s}, 18 \mathrm{H}), 0.85-1.07(\mathrm{~m}, 12 \mathrm{H}), 1.28-$ $1.49(\mathrm{~m}, 16 \mathrm{H}), 1.74-1.88(\mathrm{~m}, 2 \mathrm{H}), 4.17-4.22(\mathrm{~d}$, 4H), 7.52 (s, 2H). 
Poly\{thieno[3,2-b] thiophene-diyl-alt- $N, N^{\prime}$-bis(2octyldodecyl)-naphthalene-1,4,5,8-bis

(dicarboximide)\} (P1)

Monomer 2 (95 mg, $0.204 \mathrm{mmol}$ ), monomer 1 (200 mg, $0.203 \mathrm{mmol}), \mathrm{Pd}_{2}(\mathrm{dba})_{3}(10 \mathrm{mg}, 5 \%)$ and $\mathrm{P}(\mathrm{o}-\mathrm{tol})_{3}(10 \mathrm{mg}, 15 \%)$ were added to a $50 \mathrm{~mL}$ flask. The reaction container was flushed with $\mathrm{N}_{2}$ for $20 \mathrm{~min}$ to remove oxygen, then dry toluene $(25 \mathrm{~mL})$ was added and heated under reflux for 2 days. The reactant was cooled to ambient temperature and was added dropwise to methanol $(200 \mathrm{~mL})$. The precipitate was filtered and then dissolved in $\mathrm{CHCl}_{3}$ and quickly passed through a silica column to remove the metal catalyst. Then, the obtained $\mathbf{P} \mathbf{1}$ was subjected to Soxhlet extractions and refluxed with acetone, hexane, and $\mathrm{CHCl}_{3}$ in succession to from a dark blue solid (191.4 mg, 96.4\%). ${ }^{1} \mathrm{H}$ NMR $\left(400 \mathrm{MHz}, \mathrm{CDCl}_{3}\right): \delta 0.84-0.98(\mathrm{~m}, 12 \mathrm{H}), 1.09$ $1.42(\mathrm{br}, 64 \mathrm{H}), 2.47(\mathrm{~m}, 2 \mathrm{H}), 4.11(\mathrm{~d}, 2 \mathrm{H}), 7.66(\mathrm{~s}$, $2 \mathrm{H}), 8.87(\mathrm{~s}, 2 \mathrm{H})$. Anal. Calcd. For $\mathrm{C}_{60} \mathrm{H}_{88} \mathrm{~N}_{2} \mathrm{O}_{4} \mathrm{~S}_{2}$ (\%): C, 74.64; H, 9.19; N, 2.90. Found (\%): C, 74.63; H, 9.28; 2.49 .

Poly $\left\{4,8\right.$-dioctyloxybenzo [1,2-b;3,4- $\left.b^{\prime}\right]$ dithiophenediyl-alt-N,N'-bis(2-octyldodecyl)-naphthalene-

\section{1,4,5,8-bis(dicarboximide)\} (P2)}

The synthetic procedure for $\mathbf{P 2}$ was carried out according to the aforementioned synthesis of $\mathbf{P 1}$. P2 was obtained as a dark green solid (120 mg, $51.2 \%) .{ }^{1} \mathrm{H}$ NMR $\left(400 \mathrm{MHz}, \mathrm{CDCl}_{3}\right): \delta 0.78-0.97$ (br, 18H), 1.23-1.49 (br, 84H), 1.89-2.04 (br, 6H), 4.13-4.40(d, 8H), 7.69 (s, 2H), 8.96 (s, 2H). Anal. Calcd. For $\mathrm{C}_{80} \mathrm{H}_{122} \mathrm{~N}_{2} \mathrm{O}_{6} \mathrm{~S}_{2}$ (\%): C, 75.54; H, 9.67; $\mathrm{N}, 2.20$. Found (\%): C, 75.47; H, 9.66; N, 1.89 .

\section{Poly\{4,8-bis(2-ethylhexyloxy)benzo[1,2-b:4,5-b']} dithiophene-diyl-alt-N, $N^{\prime}$-bis(2-octyldodecyl)naphthalene-1,4,5,8-bis(dicarboximide)\} (P3)

The synthetic procedure for $\mathbf{P 3}$ was carried out according to the aforementioned synthesis of $\mathbf{P 1}$. P3 was obtained as a dark green solid $(213 \mathrm{mg}$, 90.7\%). ${ }^{1} \mathrm{H}$ NMR $\left(400 \mathrm{MHz}, \mathrm{CDCl}_{3}\right): \delta 0.74-0.95$ (br, 24H), 1.11-1.44 (br, 78H), 1.68 (br, 2H), 1.862.04 (br, 4H), 4.11-4.31 (br, 8H), 7.67 (s, 2H), 8.96 (s, $2 \mathrm{H})$. Anal. Calcd. For $\mathrm{C}_{80} \mathrm{H}_{122} \mathrm{~N}_{2} \mathrm{O}_{6} \mathrm{~S}_{2}$ (\%): C, 75.54; H, 9.67; N, 2.20. Found (\%): C, 75.38; H, $9.42 ; \mathrm{N}, 2.14$.

\section{Results and discussion}

\subsection{Synthesis and characterization}

The synthetic routes for all the polymers are illustrated in Figure 1. Monomer $\mathbf{1}$ was synthesized in a mixed solvent according to previously published reports [16, 17]. Monomer 2 was synthesized in a multistep synthesis by the reported methods in five steps shown in supporting information [18, 19]. Monomer 3a and 3b were synthesized with good yields using the same method, starting from commercially available 8-dihydrobenzo[1,2-b:4,5-b'] dithiophen-4,8-dione [20, 21]. Copolymers of P1, $\mathbf{P} 2$ and $\mathbf{P} 3$ were synthesized through Stille coupling reaction of monomer $\mathbf{1}$ and $\mathbf{2}$, monomer $\mathbf{1}$ and $\mathbf{3 a}$, monomer $\mathbf{1}$ and $\mathbf{3 b}$, respectively. All the polymers have good solubility in chloroform, chlorobenzene, and dichlorobenznene, and the good solubility endowing them with easy soluble processibility for the applications in organic photovoltaics (OPVs) and other optoelectronic devices. The number-average molecular weight $\left(M_{\mathrm{n}}\right)$ and weight-average molecular weights $\left(M_{\mathrm{w}}\right)$ of $\mathbf{P 1}, \mathbf{P} 2$ and $\mathbf{P 3}$ were determined by gel permeation chromatography (GPC) using polystyrene as standard in THF eluent, and the detailed GPC data are listed in Table 1. As shown in Table $1 M_{\mathrm{n}}$ and $M_{\mathrm{w}}$ of $\mathbf{P 1}$ are much bigger than those of $\mathbf{P 2}$ and $\mathbf{P 3}$. It might be ascribed to less side chain of $\mathbf{P 1}$, which affected the arrangement of the polymer. Moreover, the steric hindrance of side chain could produce detrimental effects on polymerization [22]. Thermal stability of the copolymers was investigated with thermogravimetric analysis (TGA) and the data are listed in Table 1. The TGA analysis reveals that the onset points of the weight loss with 5\% weight-loss temperature $\left(T_{\mathrm{d}}\right)$ for $\mathbf{P 1}, \mathbf{P 2}$ and $\mathbf{P 3}$ are 438,325 and $322^{\circ} \mathrm{C}$ in the nitrogen, which indicated that all of them have good thermal stability [23]. From the DSC measurement, a glass transition temperature was not observed from the ambient temperature to $280^{\circ} \mathrm{C}$ for all of the polymers.

\subsection{Optical properties}

Figures 2 and 3 show the UV-vis absorption spectra of $\mathbf{P 1}, \mathbf{P 2}$ and $\mathbf{P 3}$, which were measured in both dilute $\mathrm{CHCl}_{3}$ and in the thin films, respectively. The optical properties of the main parameters are listed 


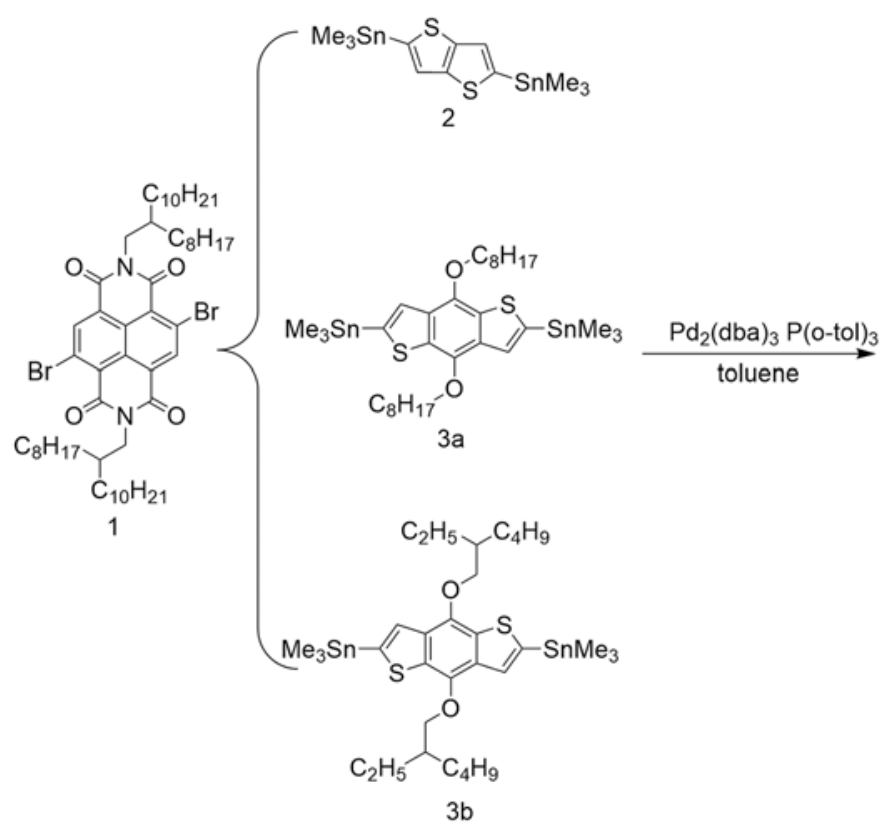

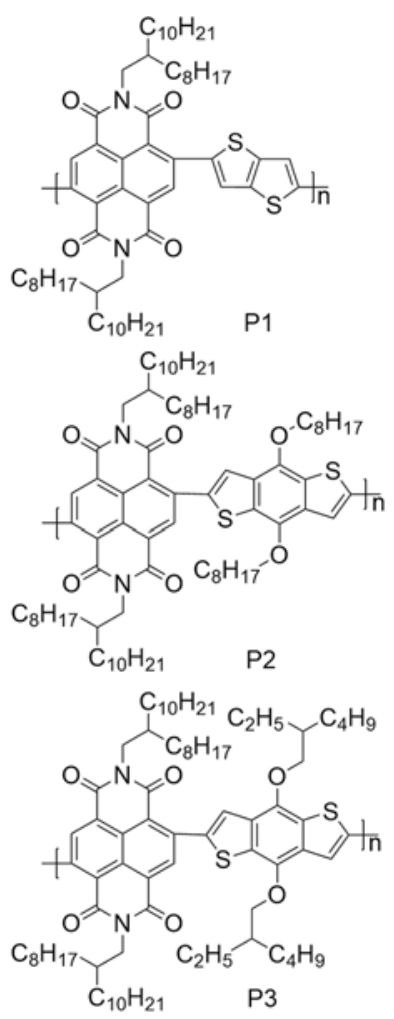

Figure 1. Synthesis routes for $\mathbf{P 1}, \mathbf{P 2}$ and $\mathbf{P 3}$

in Table 2. It can be shown in Figure 2 that $\mathbf{P 1}$ showed a maximum absorption around $654 \mathrm{~nm}$ in thin film, which undergoes a red-shift of $17 \mathrm{~nm}$ compared to that in $\mathrm{CHCl}_{3}$ solution, indicating a somewhat greater degree of organization in the thin film

Table 1. Polymerization results and thermal properties of P1, P2 and P3

\begin{tabular}{|l|c|c|c|c|}
\hline Polymer & $\begin{array}{c}\text { Mn } \\
{\left[\mathbf{1 0}^{\mathbf{3}}\right]}\end{array}$ & $\begin{array}{c}\text { Mw } \\
{\left[\mathbf{1 0}^{\mathbf{3}}\right]}\end{array}$ & PDI & $\begin{array}{c}\text { Td } \\
{\left[{ }^{\circ} \mathbf{C}\right]}\end{array}$ \\
\hline P1 & 97.18 & 348.52 & 3.59 & 438 \\
\hline P2 & 32.42 & 123.38 & 3.81 & 325 \\
\hline P3 & 20.63 & 53.95 & 2.62 & 322 \\
\hline
\end{tabular}

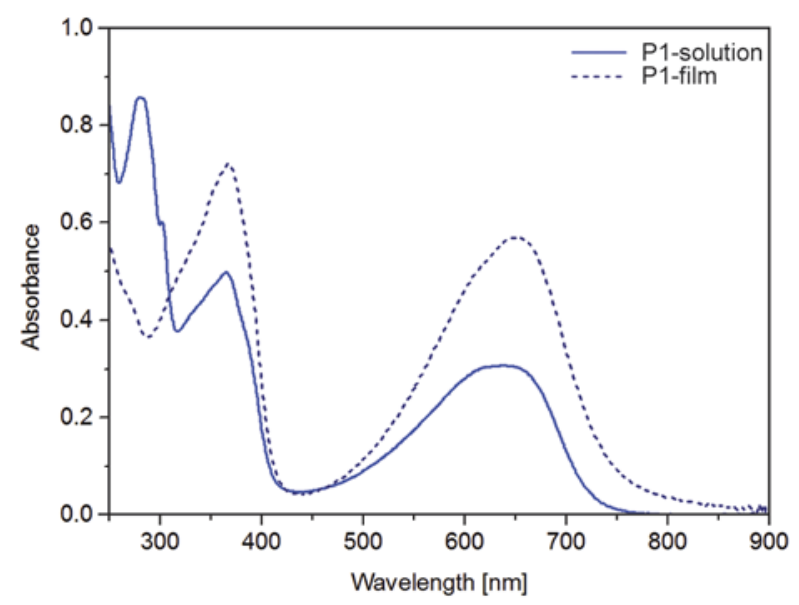

Figure 2. UV-vis absorption spectra of $\mathbf{P 1}$ in the $\mathrm{CHCl}_{3}$ solution and the thin film
[24]. The band gap of $\mathbf{P 1}$ calculated from the onset of the absorption maxima is about $1.67 \mathrm{eV}$. From Figure 3, we can see that $\mathbf{P 2}$ and $\mathbf{P 3}$ have one band in the shorter wavelengths region $(400-500 \mathrm{~nm})$ with the absorption peaks around 479 and $472 \mathrm{~nm}$, respectively. These peaks are attributed to localized $\pi-\pi^{*}$ transitions (LT), and the peaks at longer wavelengths $(500-700 \mathrm{~nm})$ are due to intramolecular charge transfer (ICT) band between donors units and naphthalene diimide acceptors units. The maximum absorption peak of $\mathbf{P} \mathbf{2}$ shifted toward longer wavelengths for about $11 \mathrm{~nm}$ from the solution state

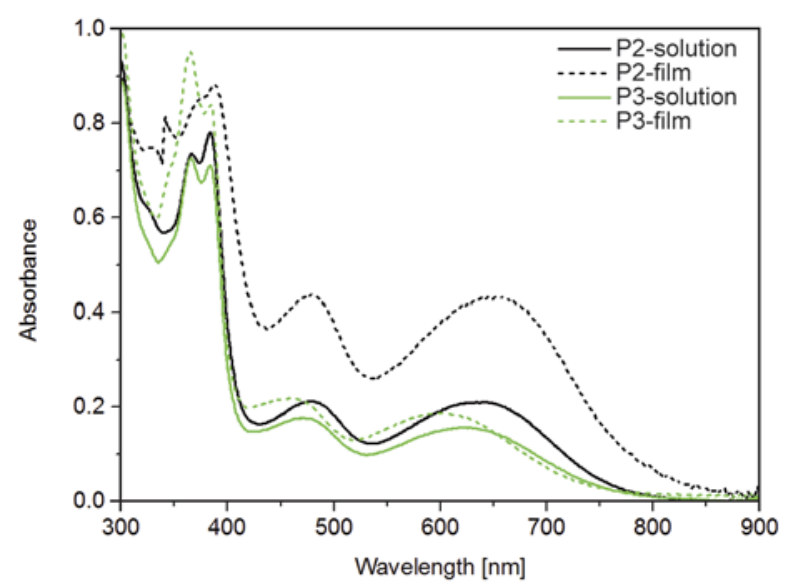

Figure 3. UV-vis absorption spectra of $\mathbf{P 2}$ and $\mathbf{P 3}$ in the $\mathrm{CHCl}_{3}$ solution and the thin film 
Table 2. Optical properties of P1, P2 and P3

\begin{tabular}{|l|c|c|c|c|c|c|}
\hline \multirow{2}{*}{ Polymer } & \multicolumn{2}{|c|}{ Chloroform solution } & \multicolumn{3}{|c|}{ Thin film } \\
\cline { 2 - 7 } & $\begin{array}{c}\lambda_{\max } \\
{[\mathbf{n m}]}\end{array}$ & $\begin{array}{c}\lambda_{\text {onset }} \\
{[\mathbf{n m}]^{\mathbf{a}}}\end{array}$ & $\begin{array}{c}\mathbf{E}_{\mathbf{g}}^{\text {opt }} \\
{[\mathbf{e V}]}\end{array}$ & $\begin{array}{c}\lambda_{\max } \\
{[\mathbf{n m}]}\end{array}$ & $\begin{array}{c}\boldsymbol{\lambda}_{\text {onset }} \\
{[\mathbf{n m}]}\end{array}$ & $\begin{array}{c}\mathbf{E}_{\mathbf{g}}^{\mathbf{o p t}} \\
{[\mathbf{e V}]^{\mathbf{b}}}\end{array}$ \\
\hline P1 & 637 & 726 & 1.71 & 654 & 744 & 1.67 \\
\hline P2 & 641 & 768 & 1.61 & 652 & 792 & 1.57 \\
\hline P3 & 621 & 759 & 1.63 & 600 & 733 & 1.69 \\
\hline
\end{tabular}

${ }^{a}$ Calculated from the onset of the absorption maxima in the $\mathrm{CHCl}_{3}$ solution.

${ }^{b}$ Calculated from the onset of the absorption maxima in the thin films prepared by spin-coating.

to the solid state, indicating the formation of inducing strong $\pi-\pi^{*}$ stacked structure [25]. In contrast, the maximum absorption peak of $\mathbf{P 3}$ shifted toward shorter wavelengths for about $21 \mathrm{~nm}$ from the solution state to the solid state. This phenomenon may be attributed to the irregular molecular arrangement of the more branched chains in $\mathbf{P 3}$, which leads to the decreased intramolecular charge transfer [26]. The band gap $\left(E_{\mathrm{g}}\right)$ of $\mathbf{P} \mathbf{2}$ and $\mathbf{P} \mathbf{3}$ calculated from the onset of the absorption maxima are according to the Equation (1).

The $E_{\mathrm{g}}$ of $\mathbf{P} 2$ and $\mathbf{P} \mathbf{3}$ were 1.57 and $1.69 \mathrm{eV}$, respectively:

$E_{\mathrm{g}}=\frac{1240}{\lambda_{\text {onset }}}$

\subsection{Electrochemical properties}

Cyclic voltammetry (CV) was employed to examine the electrochemical properties and evaluate the HOMO and LUMO levels of the polymers. Figures 4 and 5 show the cyclic voltammograms of P1, P2 and $\mathbf{P 3}$ films on the platinum button working elec-

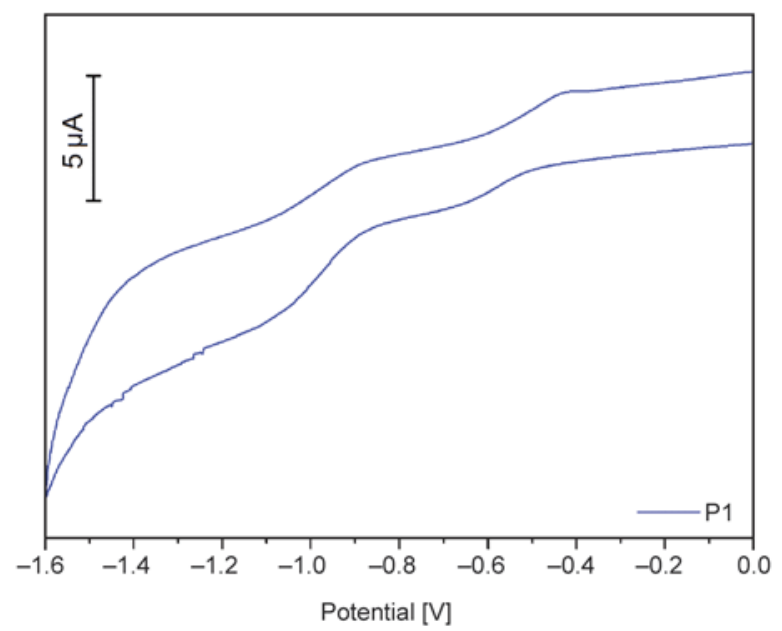

Figure 4. Cyclic voltammograms of $\mathbf{P 1}$, measured in $0.1 \mathrm{~mol} / \mathrm{L} \mathrm{Bu}_{4} \mathrm{NPF}_{6}$ acetonitrile solution, scan rate $=100 \mathrm{mV} / \mathrm{s}$

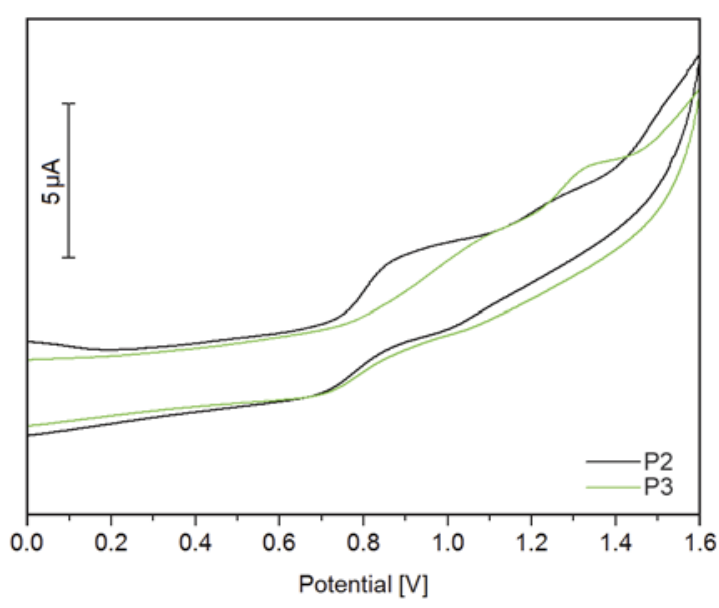

Figure 5. Cyclic voltammograms of $\mathbf{P} 2$ and $\mathbf{P} 3$, measured in $0.1 \mathrm{~mol} / \mathrm{L} \mathrm{Bu}_{4} \mathrm{NPF}_{6}$ acetonitrile solution, scan rate $=100 \mathrm{mV} / \mathrm{s}$

Table 3. Electrochemical properties of $\mathbf{P 1}, \mathbf{P 2}$ and $\mathbf{P 3}$

\begin{tabular}{|l|c|c|c|c|}
\hline Polymer & $\begin{array}{c}\mathbf{E}_{\text {ox }} \\
{[\mathbf{e V}]}\end{array}$ & $\begin{array}{c}\mathbf{E}_{\text {red }} \\
{[\mathrm{eV}]}\end{array}$ & $\begin{array}{c}\text { HOMO } \\
{[\mathrm{eV}]}\end{array}$ & $\begin{array}{c}\text { LUMO } \\
{[\mathrm{eV}]}\end{array}$ \\
\hline P1 & - & -0.52 & -5.49 & -3.82 \\
\hline P2 & 0.74 & - & -5.08 & -3.51 \\
\hline P3 & 0.77 & - & -5.11 & -3.42 \\
\hline
\end{tabular}

trode of $2 \mathrm{~mm}$ diameter, using a platinum wire counter electrode, and an $\mathrm{Ag} / \mathrm{AgCl}$ reference electrode in a $0.1 \mathrm{~mol} / \mathrm{L} \mathrm{Bu}_{4} \mathrm{NPF}_{6}$ acetonitrile solution. $\left(\mathrm{Fc} / \mathrm{Fc}^{+}\right)$was used as the internal standard. The results of the electrochemical measurements are listed in Table 3. HOMO and LUMO energy levels as well as the band gap were calculated according to the Equation (2), (3) and (4) [27]:

$\mathrm{HOMO}[\mathrm{eV}]=-\mathrm{e}\left(E_{\mathrm{ox}}^{\mathrm{onset}}+4.34\right)[\mathrm{eV}]$

$\mathrm{LuMO}[\mathrm{eV}]=-\mathrm{e}\left(E_{\mathrm{red}}^{\text {onset }}+4.34\right)[\mathrm{eV}]$

$\mathrm{Eg}[\mathrm{eV}]=-(\mathrm{HOMO}[\mathrm{eV}]-\mathrm{LUMO}[\mathrm{eV}])$

On the cathodic sweep, P1 showed an onset reduction potential of $-0.52 \mathrm{~V}$. According to the equations, the LUMO energy level of $\mathbf{P 1}$ is $-3.82 \mathrm{eV}$, and the HOMO energy level of $\mathbf{P 1}$ is $-5.49 \mathrm{eV}$. The deep HOMO levels of $\mathbf{P 1}$ should be beneficial to its chemical stability in ambient conditions. Zhou et al. [28], reported that LUMO energy levels of perylene diimide based polymers are lower than $3.6 \mathrm{eV}$ as acceptors for application in PSCs, so we used P1 as an acceptor in the active layer blend. In contrast, the anodic sweep showed onset oxidation potentials of $0.74 \mathrm{~V}$ for $\mathbf{P} 2$ and $0.77 \mathrm{~V}$ for $\mathbf{P 3}$. The HOMO energy 
levels of $\mathbf{P 2}$ and $\mathbf{P 3}$ are at -5.08 and $-5.11 \mathrm{eV}$, respectively. The LUMO levels of $\mathbf{P} \mathbf{2}$ and $\mathbf{P} \mathbf{3}$ are at -3.51 and $-3.42 \mathrm{eV}$, respectively, which implies that they could have more effective charge transfer to $\mathrm{PC}_{61} \mathrm{BM}$ than $\mathrm{P} 3 \mathrm{HT}$ 's charge transfer to $\mathrm{PC}_{61} \mathrm{BM}$ [29].

\subsection{Photovoltaic properties}

To investigate the photovoltaic properties of the polymers, we fabricated OPV devices, and the structures of the devices were ITO/PEDOT:PSS/P3HT: $\mathbf{P 1} / \mathrm{Ca} / \mathrm{Al}$ and ITO/PEDOT:PSS/P2(P3): $\mathrm{PC}_{61} \mathrm{BM} /$ $\mathrm{Ca} / \mathrm{Al}$. Figures 6 and 7 show the current-voltage $(J-V)$ curves of PSCs based on P1, P2 and P3. The photovoltaic parameters of the PSCs are summarized in Table 4. The active layer blends for all polymers were spin coated from chlorobenzene solution. We optimized the ratio of P3HT to $\mathbf{P 1}$ (1:1 to 4:1) in the active layer and the ratio of $\mathbf{P} 2$ and $\mathbf{P 3}$ to $\mathrm{PC}_{61} \mathrm{BM}$

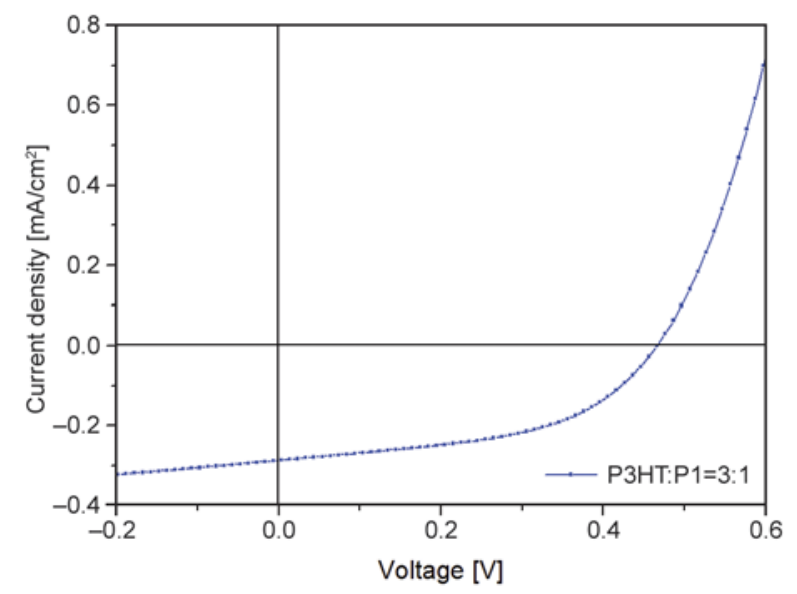

Figure 6. $J-V$ curves of the photovoltaic cells based on P1 under the illumination of AM $1.5,100 \mathrm{Mw} / \mathrm{cm}^{2}$

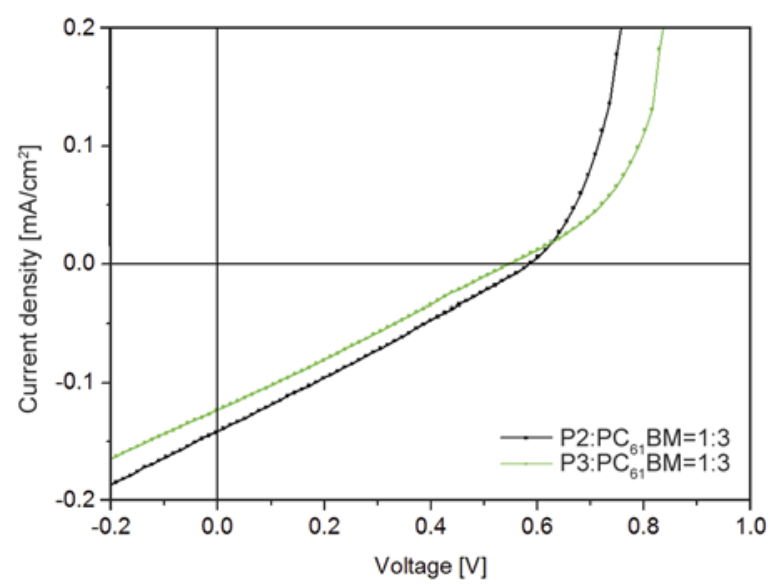

Figure 7. $J-V$ curves of the photovoltaic cells based on $\mathbf{P 2}$ and $\mathbf{P 3}$ under the illumination of AM 1.5, $100 \mathrm{Mw} / \mathrm{cm}^{2}$
Table 4. Photovoltaic properties of the photovoltaic cells

\begin{tabular}{|l|c|c|c|c|c|}
\hline Polymer & $\begin{array}{c}\text { D:A } \\
\text { ratio }\end{array}$ & $\begin{array}{c}\mathbf{V}_{\text {oc }} \\
{[\mathbf{V}]}\end{array}$ & $\begin{array}{c}\mathbf{J}_{\text {sc }} \\
{\left[\mathbf{m A} / \mathbf{c m}^{2}\right]}\end{array}$ & $\begin{array}{c}\mathbf{F F} \\
{[\mathbf{\%}]}\end{array}$ & $\begin{array}{c}\mathbf{P C E} \\
{[\mathbf{\%}]}\end{array}$ \\
\hline $\mathbf{P 1}^{\mathrm{a}}$ & $3: 1$ & 0.47 & 0.29 & 49.5 & 0.068 \\
\hline $\mathbf{P 2}^{\mathrm{b}}$ & $1: 3$ & 0.56 & 0.14 & 27.1 & 0.021 \\
\hline $\mathbf{P 3}^{\mathrm{b}}$ & $1: 3$ & 0.49 & 0.12 & 27.2 & 0.017 \\
\hline
\end{tabular}

${ }^{a} \mathbf{P 1}$ as acceptor and $\mathrm{P} 3 \mathrm{HT}$ as donor.

${ }^{\mathrm{b}} \mathbf{P} 2$ and $\mathbf{P} 3$ as donor and $\mathrm{PC}_{61} \mathrm{BM}$ as acceptor.

(1:1 to $1: 3)$. And all the devices were annealed at $120^{\circ} \mathrm{C}$ for $10 \mathrm{~min}$.

From the cyclic voltammetry test, we can see that P1 showed n-type semiconductor properties. So P1 can be used as the acceptor in the active layer to fabricate the devices. Under standard global AM 1.5 solar conditions, the photovoltaic cells based on P3HT:P1 with a ratio of 3:1 showed the highest PCE of $0.068 \%$. Compared with these reported polymers, $\mathbf{P} 1$ had longer alkyl chains which can lead to good solubility [28, 30, 31]. However, larger alkyl chains may affect the aggregation of the molecules, thus the surface morphology of the spin coated films. It may be the main reason of the lower efficiency of the solar cells than the reported polymers. Photovoltaic cells based on $\mathbf{P 1}$ have a relatively high fill factor (FF) with the maximum of 49.5\%. Form the data in Table 4, the FF value for $\mathbf{P 1}$ devices was higher than those for $\mathbf{P 2}$ and $\mathbf{P 3}$. The reason may come from the more side alkoxy chain of $\mathbf{P 2}$ and $\mathbf{P} \mathbf{3}$ than those of $\mathbf{P 1}$ which are not favorable the aggregation of the molecules. Thus, with a low equivalent series resistance and a higher equivalent shunt resistance, $\mathbf{P 1}$ devices produced less of the currents which were dissipated in internal losses. According to the cyclic voltammetry result, $\mathbf{P 2}$ and $\mathbf{P 3}$ showed p-type semiconductor properties, therefore, they were used as the donor in the active layer. PSCs based on $\mathbf{P 2}: \mathrm{PC}_{61} \mathrm{BM}$ and P3: $\mathrm{PC}_{61} \mathrm{BM}$ in a ratio of $1: 3$ showed the highest PCEs of 0.021 and $0.017 \%$, respectively. As reported, the photovoltaic properties of conjugated polymers are very susceptible to molecular structure, even for the conjugated polymers with identical conjugated main chain while different side chain [32]. Thus, the PCEs of $\mathbf{P 2}$ we obtained were better than that of $\mathbf{P} 3$ in the same ratio of donor to acceptor. Moreover, Jsc and the efficiency of all the photovoltaic cells based on $\mathbf{P 2}$ and $\mathbf{P} \mathbf{3}$ are relatively low, probably due to more of side alkoxy chain in $\mathbf{P 2}$ and $\mathbf{P 3}$ which can affect the arrangement of the molecules. It is 
unfavorable to charge transfer between donor and acceptor materials.

\subsection{Atomic force microscopy (AFM) characterization}

To understand the relationship between device performances and active layer morphology, AFM measurements were conducted to investigate the surface morphology of P3HT:P1 (3:1, w/w), P2: PC $_{60} \mathrm{BM}$ $(1: 3, \mathrm{w} / \mathrm{w})$, and $\mathbf{P} 3: \mathrm{PC}_{60} \mathrm{BM}(1: 3, \mathrm{w} / \mathrm{w})$ blend films. As shown in Figure 8a, a larger surface roughness and domain size are observed in $\mathbf{P} \mathbf{1}$ with less bulky side chains. In contrast, significantly more homogeneous morphologies are observed from Figures $8 \mathrm{~b}$ and $8 \mathrm{c}$. Especially more of nanoscale phase separa-
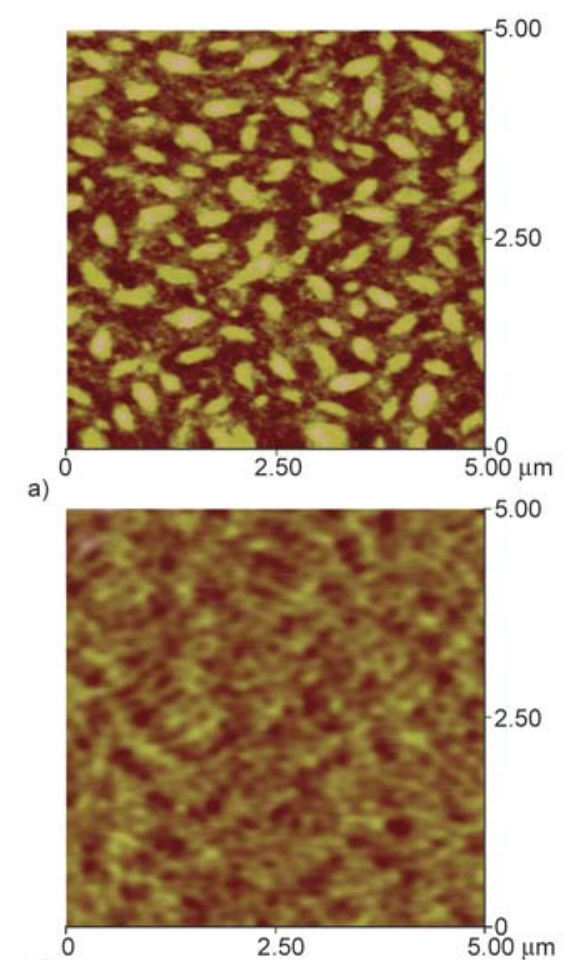

b)

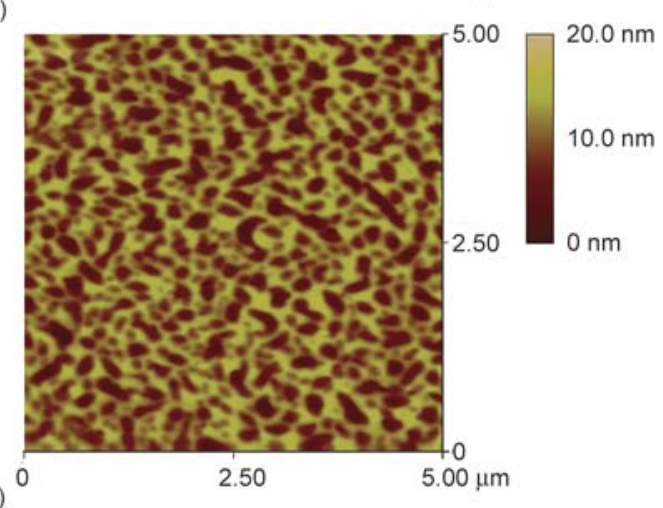

Figure 8. AFM height images $\left(5 \times 5 \mu^{2}\right)$ of (a) P3HT: P1 (3:1, w/w), (b) P2: $\mathrm{PC}_{60} \mathrm{BM}(1: 3, \mathrm{w} / \mathrm{w})$, and (c) P3: $\mathrm{PC}_{60} \mathrm{BM}(1: 3, \mathrm{w} / \mathrm{w})$ blend films spin coated from chlorobenzene tion and bicontinuous interpenetrating networks can be observed in Figure 8b, which interprets that $\mathbf{P 2}$ has more efficient charge separation and transport than P3, and $\mathbf{P 2}$ shows higher Jsc than P3 just as reported in Table 4 [33].

\section{Conclusions}

In summary, we have successfully synthesized three D-A copolymers containing naphthalenediimide units. All polymers exhibit moderate to high molecular weights, excellent thermal stability and good solubility in common organic solvents. The optical and electrochemical properties indicated that the polymers have broad absorption range and low band gap. With different electron-rich donor units, P1 shows n-type semiconductor properties, P2 and P3 show p-type semiconductor properties. For the first time, the PSCs based on P1, P2 and P3 were fabricated, with preliminary PCEs of $0.068,0.021$ and $0.017 \%$, respectively. We suppose to change the side chain of the polymers to get a high mobility and optimize the fabricating process of the devices by spinning coated in different solvents and anneal at different temperature, which is our current research interest.

\section{Acknowledgements}

The authors express their sincere thanks to Yunbin Hu, Zheng Zhao, Yu Xiong, Jie Li and Prof. Xike Gao in Laboratory of Materials Science, Shanghai Institute of Organic Chemistry for their help in synthesis. This work is supported by Doctoral Fund of Ministry of Education of China (20090075120011), and The National Natural Science Foundation of China (51003012).

\section{References}

[1] Li Y., Guo Q., Li Z., Pei J., Tian W.: Solution processable D-A small molecules for bulk-heterojunction solar cells. Energy and Environmental Science, 3, 1427-1436 (2010).

DOI: $10.1039 / \mathrm{C} 003946 \mathrm{~B}$

[2] Treat N. D., Shuttle C. G., Toney M. F., Hawker C. J., Chabinyc M. L.: In situ measurement of power conversion efficiency and molecular ordering during thermal annealing in P3HT:PCBM bulk heterojunction solar cells. Journal of Materials Chemistry, 21, 1522415231 (2011). DOI: $10.1039 / \mathrm{C} 1 \mathrm{JM} 12677 \mathrm{~F}$

[3] Heeger A. J.: Semiconducting polymers: The third generation. Chemical Society Reviews, 39, 23542371 (2010).

DOI: $10.1039 / B 914956 \mathrm{M}$ 
[4] Brabec C. J., Sariciftci N. S., Hummelen J. C.: Plastic solar cells. Advanced Functional Materials, 11, 15-26 (2001).

DOI: $10.1002 / 1616-3028(200102) 11: 1<15::$ AIDADFM15>3.0.CO;2-A

[5] Jørgensen M., Norrman K., Gevorgyan S. A., Tromholt T., Andreasen B., Krebs F. C.: Stability of polymer solar cells. Advanced Materials, 24, 580-612 (2012). DOI: 10.1002/adma.201104187

[6] Huo L., Huo J., Chen H-Y., Zhang S., Jiang Y., Chen T. L., Yang Y.: Bandgap and molecular level control of the low-bandgap polymers based on 3,6-dithiophen-2yl-2,5-dihydropyrrolo[3,4-c]pyrrole-1,4-dione toward highly efficient polymer solar cells. Macromolecules, 42, 6564-6571 (2009).

DOI: $10.1021 / \mathrm{ma} 9012972$

[7] Liang Y., Feng D., Wu Y., Tsai S-T., Li G., Ray C., Yu L.: Highly efficient solar cell polymers developed via fine-tuning of structural and electronic properties. Journal of the American Chemical Society, 131, 7792-7799 (2009). DOI: $10.1021 / \mathrm{ja} 901545 \mathrm{q}$

[8] Liang Y., Xu Z., Xia J., Tsai S-T., Wu Y., Li G., Ray C., Yu L.: For the bright future-bulk heterojunction polymer solar cells with power conversion efficiency of 7.4\%. Advanced Materials, 22, E135-E138 (2010). DOI: $10.1002 / \mathrm{adma} .200903528$

[9] Zhu Y., Champion R. D., Jenekhe S. A.: Conjugated donor-acceptor copolymer semiconductors with large intramolecular charge transfer: Synthesis, optical properties, electrochemistry, and field effect carrier mobility of thienopyrazine-based copolymers. Macromolecules, 39, 8712-8719 (2006).

DOI: $10.1021 / \mathrm{ma} 061861 \mathrm{~g}$

[10] Durban M. M., Kazarinoff P. D., Luscombe C. K.: Synthesis and characterization of thiophene-containing naphthalene diimide n-type copolymers for OFET applications. Macromolecules, 43, 6348-6352 (2010). DOI: $10.1021 / \mathrm{ma100997g}$

[11] Yan H., Chen Z., Zheng Y., Newman C., Quinn J. R., Dötz F., Kastler M., Facchetti A.: A high-mobility electron-transporting polymer for printed transistors. Nature, 457, 679-686 (2009).

DOI: $10.1038 /$ nature 07727

[12] Gao X., Di C-A., Hu Y., Yang X., Fan H., Zhang F., Liu Y., Li H., Zhu D.: Core-expanded naphthalene diimides fused with 2-(1,3-dithiol-2-ylidene)malonitrile groups for high-performance, ambient-stable, solution-processed n-channel organic thin film transistors. Journal of the American Chemical Society, 132, $3697-$ 3699 (2010). DOI: $10.1021 /$ ja910667y

[13] Kudla C. J., Dolfen D., Schottler K. J., Koenen J-M., Breusov D., Allard S., Scherf U.: Cyclopentadithiazolebased monomers and alternating copolymers. Macromolecules, 43, 7864-7867 (2010).

DOI: $10.1021 / \mathrm{ma} 1014885$
[14] Ahmed E., Ren G., Kim F. S., Hollenbeck E. C., Jenekhe S. A.: Design of new electron acceptor materials for organic photovoltaics: Synthesis, electron transport, photophysics, and photovoltaic properties of oligothiophene-functionalized naphthalene diimides. Chemistry of Materials, 23, 4563-4577 (2011).

DOI: $10.1021 / \mathrm{cm} 2019668$

[15] Mishra A., Bäuerle P.: Small molecule organic semiconductors on the move: promises for future solar energy technology. Angewandte Chemie International Edition, 51, 2020-2067 (2012).

DOI: $10.1002 /$ anie.201102326

[16] Thalacker C., Röger C., Würthner F.: Synthesis and optical and redox properties of core-substituted naphthalene diimide dyes. Journal of Organic Chemistry, 71, 8098-8105 (2006).

DOI: $10.1021 /$ jo0612269

[17] Chen Z., Zheng Y., Yan H., Facchetti A.: Naphthalenedicarboximide- vs perylenedicarboximide-based copolymers. Synthesis and semiconducting properties in bottom-gate n-channel organic transistors. Journal of the American Chemical Society, 131, 8-9 (2009). DOI: $10.1021 / \mathrm{ja} 805407 \mathrm{~g}$

[18] Fuller L. S., Iddon B., Smith K. A.: Thienothiophenes. Part 2. ${ }^{1}$ Synthesis, metallation and bromine $\rightarrow$ lithium exchange reactions of thieno[3,2- $b]$ thiophene and its polybromo derivatives. Journal of the Chemical Society, Perkin Transactions 1, 1, 3465-3470 (1997). DOI: 10.1039/A701877K

[19] Yuan Z., Xiao Y., Yang Y., Xiong T.: Soluble ladder conjugated polymer composed of perylenediimides and thieno[3,2-b]thiophene (LCPT): A highly efficient synthesis via photocyclization with the sunlight. Macromolecules, 44, 1788-1791 (2011).

DOI: $10.1021 / \mathrm{ma1} 026252$

[20] Wen S., Cheng W., Li P., Yao S., Xu B., Li H., Gao Y., Wang Z., Tian W.: Synthesis and photovoltaic properties of thieno[3,4-c]pyrrole-4,6-dione-based donoracceptor copolymers. Journal of Polymer Science Part A: Polymer Chemistry, 50, 3758-3766 (2012). DOI: $10.1002 /$ pola.26164

[21] Chen J., Shi M-M., Hu X-L., Wang M., Chen H-Z.: Conjugated polymers based on benzodithiophene and arylene imides: Extended absorptions and tunable electrochemical properties. Polymer, 51, 2897-2902 (2010). DOI: $10.1016 /$ j.polymer.2010.04.035

[22] Li Y.: Molecular design of photovoltaic materials for polymer solar cells: Toward suitable electronic energy levels and broad absorption. Accounts of Chemical Research, 45, 723-733 (2012). DOI: $10.1021 / \operatorname{ar} 2002446$

[23] Cao J., Zhang W., Xiao Z., Liao L., Zhu W., Zou Q., Ding L.: Synthesis and photovoltaic properties of low band gap polymers containing benzo[1,2-b:4,5-c' $]$ dithiophene-4,8-dione. Macromolecules, 45, 1710-1714 (2012). DOI: $10.1021 / \mathrm{ma} 202578 \mathrm{y}$ 
[24] Zhang M., Guo X., Li Y.: Photovoltaic performance improvement of D-A copolymers containing bithiazole acceptor unit by using bithiophene bridges. Macromolecules, 44, 8798-8804 (2011).

DOI: $10.1021 / \mathrm{ma} 201976 \mathrm{t}$

[25] Wang X., Sun Y., Chen S., Guo X., Zhang M., Li X., Li Y., Wang H.: Effects of $\pi$-conjugated bridges on photovoltaic properties of donor- $\pi$-acceptor conjugated copolymers. Macromolecules, 45, 1208-1216 (2012). DOI: $10.1021 / \mathrm{ma} 202656 \mathrm{~b}$

[26] Wakim S., Alem S., Li Z., Zhang Y., Tse S-C., Lu J., Ding J., Tao Y.: New low band gap thieno[3,4-b]thiophene-based polymers with deep HOMO levels for organic solar cells. Journal of Materials Chemistry, 21, 10920-10928 (2011).

DOI: $10.1039 / \mathrm{c} 1 \mathrm{jm} 11229 \mathrm{e}$

[27] Chen S., Bolag A., Nishida J-I., Yamashita Y.: n-type field-effect transistors based on thieno[3,2-b]thiophene2,5-dione and the bis(dicyanomethylene) derivatives. Chemistry Letters, 40, 998-1000 (2011).

DOI: $10.1246 / \mathrm{cl} .2011 .998$

[28] Zhou E., Cong J., Wei Q., Tajima K., Yang C., Hashimoto K.: All-polymer solar cells from perylene diimide based copolymers: Material design and phase separation control. Angewandte Chemie International Edition, 50, 2799-2803 (2011). DOI: $10.1002 /$ anie. 201005408
[29] Lin L-Y., Chen Y-H., Huang Z-H., Lin H-W., Chou SH., Lin F., Chen C-W., Liu Y-H., Wong K-T.: A lowenergy-gap organic dye for high-performance smallmolecule organic solar cells. Journal of the American Chemical Society, 133, 15822-15825 (2011). DOI: $10.1021 / \mathrm{ja} 205126 \mathrm{t}$

[30] Zhou E., Cong J., Zhao M., Zhang L., Hashimoto K., Tajima K.: Synthesis and application of poly(fluorenealt-naphthalene diimide) as an n-type polymer for allpolymer solar cells. Chemical Communications, 48, 5283-5285 (2012).

DOI: $10.1039 / C 2 C C 31752 \mathrm{D}$

[31] Hwang Y-J., Ren G., Murari N. M., Jenekhe S. A.: ntype naphthalene diimide-biselenophene copolymer for all-polymer bulk heterojunction solar cells. Macromolecules, 45, 9056-9062 (2012).

DOI: $10.1021 / \mathrm{ma3} 020239$

[32] Nam C-Y., Qin Y., Park Y. S., Hlaing H., Lu X., Ocko B. M., Black C. T., Grubbs R. B.: Photo-cross-linkable azide-functionalized polythiophene for thermally stable bulk heterojunction solar cells. Macromolecules, 45, 2338-2347 (2012).

DOI: $10.1021 / \mathrm{ma3} 001725$

[33] Bedford N. M., Dickerson M. B., Drummy L. F., Koerner H., Singh K. M., Vasudev M. C., Durstock M. F., Naik R. R., Steckl A.: Nanofiber-based bulk-heterojunction organic solar cells using coaxial electrospinning. Advanced Energy Materials, 2, 1136-1144 (2012). DOI: $10.1002 /$ aenm.201100674 